\section{Towards Self Sufficiency}

InDrA and Pakistan have good reason to feel euphoric about the 1967-68 food grain harvests. They are going to exceed by far the all time record harvests of 1964-65. In India the yield of all food grains in 1964-65 was 89 million tons, but this year's harvest will certainly reach 95 million tons and some estimates put it as high as 100-105 million tons. Likewise, in Pakistan the 1964-65 harvest of wheat was 4.5 million tons and 11.7 million tons of rice. Last year, the yields dropped to $4 \cdot 3$ million tons and $10 \cdot 7$ million tons respectively, but this year the wheat harvest should be well in excess of 6 million tons and the rice harvest should exceed 12 million tons.

How have these remarkable increases in cereal production been achieved? Three factors can reasonably be eliminated. The weather this year has been good but not distinctively better than in 1964-65. With so many unemployed in both countries, it is difficult to believe that the record harvests have resulted from more manpower on the farms and, although irrigation has been increasing steadily, irrigation, of course, makes its greatest impact in bad, not good, seasons. Fertilizers, improved seed strains and possibly improved plant protection seem to be the answer. Both India and Pakistan have imported Mexipac wheat from Mexico (Nature, 218, 214; 1968) and Pakistan has Irri rice from Japan, but new strains alone cannot be the answer because Mexipac needs quite large applications of fertilizers and without them it is probably less successful than the strains grown previously. The fact that the greatest increases of production have been achieved on the larger and better managed farms, usually owned by the rich and politically powerful, who stand a better chance of getting new seeds and fertilizers, which are both in short supply, supports this conclusion.

Ironically the prospect of a record harvest is presenting the Indian and Pakistan Governments with economic problems. In India, for example, if the harvest, in fact, turns out to be 10 million tons above the previous record the Indian farmers will have generated, at the cereal prices fixed by the Government, the equivalent of about $£ 400$ million of new wealth. Much of this will clearly literally be eaten on the farms rather than converted into cash, but there is the very real problem that the farmers will spend the extra rupees in their pockets on imported goods such as fertilizers and agricultural machinery, and this will worsen the country's balance of payments. Furthermore, the United States sells wheat to India for rupees and then gives the rupees to the Indian Government. Should the United States decide, in view of the record harvest, to reduce wheat supplies the Indian Government will lose this subsidy and, at the same time, have to buy more wheat from its own farmers at prices that it guarantees.

\section{Staff Power}

The Education Bill which came before the Second Reading Committee of the House of Commons in February provided for the articles of government of teacher training colleges to be ratified by the Secretary of State for Education and Science. Following discussion in that committee, and after deputations from bodies such as the Association of Teachers in Colleges and Departments of Education, an amendment to the Bill has now been made, to the effect that the instruments of government must also be approved by the Secretary of State. Until now the government of these colleges has been in the hands of local education authorities, often through sub-committees on which the academic staff of the colleges were either not represented or did not have full voting powers.

The recommendations of the Robbins report in 1964 that colleges of education should be linked with universities was not accepted, and instead a committer under Mr 'T. R. Weaver was set up to discuss the liberalization of the government of these colleges. The recommendations of the Weaver report formed the basis of the Fducation Bill, which, with its new amendments, is welcomed by the academic staff concerned. The article of government which deals with all aspects of the relationships between students and the colleges was the original candidate for ratification by the ministry, and the amendment has now calmed the fears that local power groups eould still keep the academic staff out of the government of the colleges if the instruments of government, fundamentally the constitutions of the college, were not subject to ministerial approval. Aware of the attitudes of the Department of Education and Science, most of the governing bodies of the colleges are submitting instruments and articles which provide some say for the academic staff in the running of the college, and those which are not approved are returned to the governors for reconsideration. After the successful first step of putting the teachers in control of the colleges, there then follows the question of how much students should participate in government. It seems that student participation is not a rigid requirement of the department, but recognized channels for close consultation are thought to be essential. Until now there has been the right of appeal to the department in cases of students being disciplined or sent down, but it is thought that approved articles must include provision for students to be able to appeal in the first instance to the governing body of the college.

\section{Italian Research under Fire}

THe reports on science policy produced by the Organization for Economic Development and Co-operation have so far proved worthy but unprovocative documents. But the most recent report, still officially unpublished, has caused a political stir in Italy, the country it describes. The report was written almost a year ago, and was sent to interested parties in Italy before publication-the normal practice. Since then the report has shuttled around Italian Government offices, but it appcared again last week, when a few copies were handed out by dissident research workers at the headquarters of the National Council of Research. The research workers, who had been occupying the headquarters for four days as a protest against the state of research in Italy, distributed the report as a political move designed to force the Italian Government's hand.

The report, written by three examiners (M. Jacques Spaey from Belgium, Professor Harvey Brooks from Harvard, and Professor Ourisson from Strasbourg), should have been discussed at a confrontation meeting 